$\begin{array}{lllllllllllllllllll}\text { I. } & \mathrm{R} & \mathrm{O} & \mathrm{Z} & \mathrm{P} & \mathrm{R} & \mathrm{A} & \mathrm{W} & \mathrm{Y} & \mathrm{I} & \mathrm{A} & \mathrm{R} & \mathrm{T} & \mathrm{Y} & \mathrm{K} & \mathrm{U} & \mathrm{L} & \mathrm{Y}\end{array}$

\title{
Rafal Wegrzyniak
}

\author{
WOJNA I ZAGLADA \\ Odbicie doświadczeń z lat 1939-1945 w przedstawieniach \\ i pisarstwie Erwina Axera ${ }^{1}$
}

Pamięci Jerzego Timoszewicza

1.

1 września 1939 roku Erwin Axer wraz z młodszym o dwa lata bratem Henrykiem, studiującym chemię na Politechnice Lwowskiej, zgłosił się do wojska, aby walczyć z Niemcami, którzy zaatakowali Polskę. Axerowie mieli jedynie ukończone „przysposobienie wojskowe”, nigdy nie służyli w armii, nie zostali przyjęci do niej jako ochotnicy, więc postanowili wydostać się ze Lwowa zanim zostanie zajęty przez Wehrmacht. Erwin chciał dotrzeć do swego nauczyciela z Państwowego Instytutu Sztuki Teatralnej w Warszawie, Jerzego Stempowskiego, przebywającego we Wschodnich Karpatach, w Słobodzie Rungurskiej, w pensjonacie prowadzonym przez Stanisława Vincenza. 16 września Axerowie zatrzymali się pod Kołomyją w folwarku krewnej. ${ }^{2}$ Następnego dnia pojawili się w nim krasnoarmiejcy, wylegitymowali Axerów i ,zrewidowali” oraz „zabrali broń” Erwinowi. Potem Axerowie wrócili do okupowanego przez Związek Sowiecki Lwowa, do mieszkania rodziców. Przebywali w nim żołnierze polscy i uciekinierzy z Warszawy, w tym komunistyczny poeta Władysław Broniewski z aktorką Marią Zarębińską i jej córką Marią.

Erwin otrzymał pracę w działających jeszcze pod przedwojennym kierownictwem Mieczysława Szpakiewicza Teatrach Miejskich przy porządkowaniu

\footnotetext{
1 Szkic jest rozszerzoną i uzupełnioną wersją wystąpienia wygłoszonego podczas sesji Kto to byt Erwin Axer? zorganizowanej w dniach 20-21 października 2017 w Akademii Teatralnej im. Aleksandra Zelwerowicza w Warszawie. Dziękuję Jerzemu Axerowi za jego lekturę i przekazanie szeregu uwag.

2 Zob. E. Axer, Odwrót 1939, [w:] idem, Czwarte ćwiczenia pamięci, Kraków 2003.
} 
biblioteki. ${ }^{3}$ Ale już w połowie października instytucję tę poddano sowietyzacji. ${ }^{4}$ 16 stycznia 1940 znalazł się jako aktor w zespole - powołanego 19 grudnia 1939 dekretem Rady Komisarzy Ludowych Ukraińskiej Republiki Sowieckiej - Państwowego Polskiego Teatru Dramatycznego pod dyrekcją Władimira Kurdyby, pod kierownictwem artystycznym Władysława Krasnowieckiego. W nocy z 23 na 24 stycznia 1940 NKWD aresztowało wraz z grupą polskich pisarzy jego kierownika literackiego Broniewskiego. ${ }^{5}$ Stanowisko to objęła Wanda Wasilewska, która napisała dla zespołu wystawioną wkrótce Opowieść o Bartoszu Gtowackim. Od września 1940 PPTD wyeksmitowany z gmachu Teatru Wielkiego występował w będącej niegdyś siedzibą żydowskiej sceny budzie, usytuowanej na podwórzu przy Jagiellońskiej 11. W 1940 przy boku przybyłego z Warszawy aktora Jana Kreczmara ${ }^{6}$ Axer grał w dwóch przedstawieniach przygotowanych przez Jewgienija Germana: od 2 marca Marynarza w Zatopieniu eskadry Oleksandra Kornijczuka, od 24 września zaś Sanitariusza w Pociagu pancernym (Książę Mścisław Udały) Josifa Pruta, wystawionym dla uczczenia rocznicy „wyzwolenia”, czyli przyłączenia Zachodniej Ukrainy do Związku Sowieckiego. W sezonie 1940/41 był jednym z trzech kandydatów do inscenizowania Dziadów Mickiewicza', lecz ostatecznie 28 maja 1941 wyreżyserował Pannę Maliczewska Zapolskiej z Zarębińską w roli tytułowej. PPTD działał jeszcze trzy dni po wkroczeniu Niemców do Lwowa, bo do 25 czerwca 1941.

2.

W trzeciej serii Ćwiczeń pamięci opublikowane zostało obszerne wspomnienie Erwina Axera o dwóch jego przesłuchaniach przeprowadzonych w 1968 w Warszawie przez Prokuraturę Wojskową. Gdy propaganda komunistyczna w PRL dowodziła związków pomiędzy nazizmem a syjonizmem, Axera przesłuchano jako świadka w sprawie kolaboracji z Niemcami Józefa Parnasa, pierwszego prezesa Judenratu, czyli Rady Starszych przy Gminie Żydowskiej we Lwowie. Axer nie zdołał dokończyć oświadczenia, że „wprawdzie według ustaw norymberskich i zgodnie z nimi...", w którym odwołując się do Nürnberger Rassengesetze, czyli przepisów prawa uchwalonego 15 września 1935 przez narodowych socjalistów w Niemczech, niewątpliwie zamierzał zasygnalizować, iż był uznawany za Żyda.

\footnotetext{
3 Uktadanie biografii. Z Erwinem Axerem rozmawia Elżbieta Wysińska, „Pamiętnik Teatralny” 1991 z. 3-4.

4 Zob. E. Axer, Towarzysz Szuster, czyli Preludium, [w:] idem, Ćwiczenia pamięci. Seria druga, Warszawa 1991.

5 Zob.: idem, Aresztowanie, [w:] idem, Ćwiczenia pamięci, Warszawa 1984, s. 66-68; idem, Zeznanie, [w:] idem, Ćwiczenia pamięci. Seria druga, op. cit., s. 159-65.

6 Zob. J. Kreczmar, Teatr lwowski w latach 1939-1941. Wspomnienia, „Pamiętnik Teatralny” 1963 z. 1-4, s. 234-241.

7 Zob. P. Horbatowski, Życie teatralne we Lwowie w latach 1939-1946, „Pamiętnik Teatralny” 1997 z. 1-4, s. 689-694.
} 
Jego ojciec Maurycy był bowiem członkiem Izraelickiej Gminy Wyznaniowej w Przemyślu, zawarł zaś ślub z Fryderyką Ernestyną Schuster, urodzoną w Kołomyi, a dorastającą w Drohobyczu, w synagodze miejskiej w Wiedniu. ${ }^{8}$ Axerowie byli więc zasymilowaną rodziną żydowską, która, zwłaszcza mieszkając w Baden czy w Wiedniu w końcowym okresie istnienia Austro-Węgier, ulegała germanizacji, w międzywojennym Lwowie natomiast - polonizacji. Przy czym Maurycy był wolnomyślicielem i socjaldemokratą nie przestrzegającym nakazów judaizmu. Axer utrzymywał, że Parnasa poznał jedynie „,przelotnie”, kiedy „Niemcy powiesili na balkonie” część gminy żydowskiej w jej siedzibie „koło Teatru Wielkiego”. „Kupowałem klucze w tej okolicy - zeznał Axer - bo byłem wtedy ślusarzem”.

Jednak mylił się, gdyż 1 września 1942 widział powieszonego wraz z pięcioma innymi osobami na balkonie siedziby gminy bynajmniej nie Parnasa, lecz trzeciego już prezesa lwowskiego Judenratu, również adwokata $\mathrm{z}$ tytułem doktora - Henryka Landsberga. ${ }^{10}$ Parnas został rozstrzelany przez Niemców w więzieniu przy Łąckiego 1 jeszcze w październiku 1941 za odmowę wyselekcjonowania młodych Żydów do powstającego obozu pracy przy ulicy Janowskiej. Poza tym Axer powinien znać doktora Parnasa, mającego siedemdziesiąt lat w 1941, będącego adwokatem jak jego ojciec, Maurycy, który po zajęciu Lwowa przez Niemców od 30 czerwca 1941 pracował krótko w wydziale mieszkaniowym Judenratu przy ulicy Słonecznej. Dopiero potem został zatrudniony w prowadzonym przez SS przedsiębiorstwie zbrojeniowym, a ściślej w Heereskraftwagenpark, czyli w warsztatach dla naprawy wojskowych samochodów. Przy ulicy Janowskiej 134, na północno-zachodnich peryferiach Lwowa, pracowali obaj jego synowie: Erwin jako lakiernik, a Henryk w biurze technicznym. W jednym z felietonów Axer napomknął, że w sierpniu 1941 pod okiem esesmanów wojskowe ,wozy” pokrywał „,W Janowskim obozie kolorem «feldgrau»". ${ }^{11}$ Wszyscy Axerowie od 8 lipca 1941 nosili na prawym ramieniu opaski z gwiazdą Dawida, ale codziennie dochodzili do pracy, mieszkając nadal przy ulicy Akademickiej 10.

Dopiero w październiku 1941 przy Janowskiej powstał obóz pracy, „SS- und Polizei Führer im Distrikt Galizien Zwangsarbeiterlager in Lemberg", a Henryk został w nim wraz z grupą Żydów zamknięty. Po pewnym czasie przejął w obozie kierownictwo Arbeitseinsatzu, czyli biura przydziału pracy, a dzięki zdobyciu zaufania esesmanów pomagał współwięźniom. Lecz późną jesienią 1943, niewątpliwie przed buntem, zakończonym 19 listopada masowym mordem oraz

8 Zob.: Z. Andrzejewski, Axer Maurycy, [w:] Przemyski stownik biograficzny, t. 3, Przemyś1 2016; idem, Lwowski Cicero, ,Przemyski Przegląd Kulturalny” 2008 nr 4.

9 E. Axer, Parnas, [w:] idem, Ćwiczenia pamięci. Seria trzecia, Kraków 1998, s. 152-159.

10 Zob. J. Honigsman, Zagłada Żydów lwowskich (1941-1944), przekł. i oprac. A. Redzik, Warszawa 2007, s. 29, 66, 106. W Muzeum Holocaustu w Waszyngtonie prezentowana jest makabryczna fotografia ukazująca sześć ofiar owej egzekucji.

11 E. Axer, Pokaż mi swoje sztuczki, powiedziat żotnierz..., [w:] idem, Ćwiczenia pamięci. Seria druga, op. cit., s. 18. 
ucieczką niektórych żydowskich więźniów, zacierających ślady zbrodni, został zadenuncjowany jako uczestnik obozowej konspiracji mającej kontakty z Armią Krajową. „Oprawcy torturowali” Henryka Axera przez wiele godzin, by w końcu „zakatować go na śmierć kijami”. ${ }^{22}$

W czasie powstania warszawskiego Axer przypomniał sobie, że w pierwszej połowie roku 1942, w trakcie przeprowadzania we Lwowie kolejnych akcji służących eksterminacji Żydów, ,gdy już było całkiem jasne, że wszystko źle się skończy”, Maurycy Axer w kuchni „nagle powiedział, że Ryś [czyli brat Henryk] i ja mamy zabić każdy po jednym Niemcu, kiedy oni, ojciec i matka, już zginą. Kiedy ich nie będzie.” Axer enigmatycznie dodał, że ojciec „w parę miesięcy później zginął. W jesieni czterdziestego trzeciego roku zginął także Ryś. Powinienem był zabić teraz dwóch Niemców". ${ }^{13}$

Otóż mający pięćdziesiąt sześć lat Maurycy Axer 1 września 1942, czyli dokładnie w dniu egzekucji Landsberga i innych członków Judenratu, przed swym domem, za oddanie honorów wiezionym ciężarówką polskim oficerom rezerwy został do nich dołączony zamknięty w więzieniu przy Łąckiego. Stamtąd po kilkunastu dniach wywieziony został transportem kolejowym z dworca Lwów-Kleparów do obozu zagłady w Bełżcu na Lubelszczyźnie. Z jego wagonu ,pomiędzy Kulikowem a Żółkwią" uciekło trzech Żydów i jeden z nich po powrocie do Lwowa ,jeszcze tej samej nocy" pojawił się w mieszkaniu Axerów. Z relacji owego uciekiniera wynikało, że chory na lumbago Maurycy Axer nie był w stanie wyskoczyć z pędzącego pociągu, więc został prawdopodobnie zagazowany w Bełżcu..$^{14}$

Ale niedawno, bo w styczniu 2016, w lokalnym czasopiśmie wydawanym na Podkarpaciu, ogłoszona została odmienna wersja jego śmierci, oparta na relacjach z drugiej ręki i nie mająca dotąd potwierdzenia. Adwokat jakoby zdołał wyskoczyć z pociągu, który z powodu prac prowadzonych na torach zwolnił we wsi Ostrów za miasteczkiem Radymno w okolicach Jarosławia. Uzyskał pierwszą pomoc od kobiety mieszkającej przy torach, ale ona ze względu na licznych świadków bała się go ukryć w swym domu. Po wyjściu Maurycy Axer został więc doprowadzony na posterunek przez dwóch robotników pracujących na torach i zastrzelony przez Niemców na żydowskim cmentarzu w Radymnie. ${ }^{15}$

W tym czasie Erwin Axer był ślusarzem dorabiającym klucze do mieszkań i biur dla Niemców. W Polowaniach - opublikowanych w „Dialogu” w październiku 1980,

12 Z. Andrzejewski, Ryś, „Nasz Przemyśl” 2007 nr 7, s. 6-7; zob. też: S. Gogołowska, Przyczynek do historii obozu janowskiego - Ryszard Axer, „Przegląd Lekarski” $1979 \mathrm{nr}$ 1; J. Honigsman, op. cit., s. 76.

13 E. Axer, O czlowieku, który w zemście (być może) trochę przesadził, [w:] idem, Ćwiczenia pamięci. Seria druga, op. cit., s. 43.

${ }_{14}$ Zob. Z. Andrzejewski, Axer Maurycy, op. cit., s. 26; idem, Lwowski Cicero, op. cit., s. 38.

15 Zob. J. Szwic, Jak naprawdę zginąt obrońca Gorgonowej, „Życie Podkarpackie” 27 I 2016. Dziękuję Jakubowi Szwicy i Zenonowi Andrzejewskiemu za rozmowy o okolicznościach śmierci Maurycego Axera. 
bodaj pierwszym i zarazem najbardziej otwartym opisaniu doświadczeń z czasów Zagłady, powstałym w warunkach liberalizacji cenzury w PRL - Axer zaznaczył, że go „ściągnął z obozu do warsztatu i wyuczył ślusarki” żydowski rzemieślnik Bernard Chuwen. W Nauczycielach wspominał, że pod koniec 1942, po aresztowaniu ojca i wysłaniu parę tygodni później matki pociągiem do Warszawy, jak skądinąd wiadomo pod opieką przyszłej żony Jana Kreczmara, Justyny Karpińskiej, też aktorki PPTD, gdy brat był już zamknięty w obozie, przez kilka tygodni nie miał domu. Krążył wtedy „,pomiędzy warsztatem w budynku gubernatorstwa, dawnej siedzibie wojewody”, czyli Distriktgebaüde, ,a jadłodajnią przy [tejże] ulicy Czarnieckiego”. „Odżywiałem się w stołówce dla robotników «dystryktu», niemieckiej administracji kraju zwanego «Distrikt Galizien»". ${ }^{16}$ W innym wspomnieniu Axer ujawnił, że ,przypadek sprowadził” jego i Aleksandra Winnikowa „W roku czterdziestym drugim” do „podle przepełnionego pokoju w getcie lwowskim”, gdzie ukrywało się jeszcze kilku „obcych sobie ludzi”. „Przetrwaliśmy tam wspólnie dwanaście tygodni i uciekliśmy, dotknąwszy czołem ostatniej ściany". ${ }^{17}$ Natomiast w kolejnym tekście napomknął, że od 18 listopada 1942, gdy prowadzona była „wielka akcja na Żydów”, a ściślej ogrodzono płotem getto, jego mieszkańców zaś wywożono do obozu Janowskiego albo do Bełżca, miał zagwarantowane poruszanie się po Lwowie i pozostawanie przy życiu - podobnie jak dwanaście tysięcy robotników - dzięki potwierdzeniu pracy dla potrzeb armii niemieckiej przez adiutanta gubernatora Galicji, SS-Gruppenführera doktora Ottona von Waechtera, Hauptsturmführera SS Stiasnego. „Sam żyłem jeszcze - zaznaczył Axer - dzięki takiej opasce z pieczątką i literą R: Rüstung [Uzbrojenie]. Adiutant Stiasny schował ją dla mnie w swojej kasie pancernej". ${ }^{18}$

Dlatego Axer w 1986, po spotkaniu w domu Eriki Pluhar, aktorki Burgtheater w Wiedniu, która okazała się córką mieszkającego podczas wojny we Lwowie z rodziną innego adiutanta gubernatora Galicji, nie miał wątpliwości, że esesman Stiasny ,wraz z Adamem Ostrowskim, ze Stanisławem Hubertem”, czyli dwoma polskimi prawnikami ze Lwowa, ,z naszym ukraińskim dozorcą, z nieznanym mi z nazwiska agentem policji, z SA-manem Muellerem z Bremy, z Kurkowskimi i całą rodziną Kreczmarów, należał do kilkunastu osób, którym zawdzięczam życie”. ${ }^{19} \mathrm{~W} 1980 \mathrm{w}$ Polowaniach Axer zdradził, że „doktor Bauer, ożeniony ze Szwajcarką, szef «Innere Verwaltung»», czyli administracji wewnętrznej, w swoim

16 E. Axer, Nauczyciele, [w:] idem, Ćwiczenia pamięci. Seria trzecia, op. cit., s. 129.

17 Idem, ,,Mokka”, [w:] idem, Ćwiczenia pamięci. Seria druga, op. cit., s. 183-185.

18 Idem, Ślusarz-amator, [w:] idem, Ćwiczenia pamięci. Seria druga, op. cit., s. 251. Zob. J. Honigsman, op. cit., s. 70. Honigsman wyjaśniał, że R na opasce było skrótem od słowa „Rüstungswerke”, czyli prace zbrojeniowe.

19 Idem, Rondo, czyli spotkanie, do którego mogło nie dojść, [w:] idem, Ćwiczenia pamięci. Seria druga, op. cit. , s. 12. Zob. J. Niedziela, Mała nazistowska dziewczynka. Rozmowa z Erika Pluhar, „Notatnik Teatralny” 2005 nr 36-37, s. 123-130. Pluhar, urodzona w 1939, była przekonana, że „Erwin - Żyd i ja - mała nazistowska dziewczynka - prawdopodobnie wtedy w Polsce gdzieś się zderzyliśmy”. 
domu go „namawiał do ucieczki”. „Później jedna z urzędniczek ofiarowała” mu „dokumenty swego męża, którego w lesie zastrzelili partyzanci, a jeszcze później, w czasie «akcji», przesiedziawszy trzy dni na strychu", postanowił, że jeśli przeżyje ucieknie „naprawdę". ${ }^{20} 6$ grudnia 1942 Axer, skrupulatnie sprawdzony przez niemiecki patrol „,w dworcowej ubikacji”, czy nie ma na ciele oznak właściwych męskim wyznawcom judaizmu, opuścił Lwów, wyjeżdżając pociągiem do Warszawy. W mieście tym przynajmniej przez pewien czas przebywała jego matka u siostry Jana i Jerzego Kreczmarów, Marii, wdowy po sanacyjnym działaczu Zapasiewiczu, mieszkającej z synem Zbigniewem na Mokotowie przy ulicy Ludwika Nabielaka. ${ }^{21}$

Natomiast Erwin Axer, przez blisko dwadzieścia miesięcy, bo do końca lipca 1944, ukrywał się - dysponując fałszywymi dokumentami wystawionymi na nazwisko Waleriana Gomulskiego - na Żoliborzu. Przebywał początkowo w mieszkaniu przy ulicy Zygmunta Krasińskiego w IV klatce III kolonii Warszawskiej Spółdzielni Mieszkaniowej. Był to dom znanego mu z Wydziału Sztuki Reżyserskiej PIST-u oraz pobytu wraz z bratem Janem w okupowanym przez Sowietów Lwowie filozofa, Jerzego Kreczmara oraz jego żony, Felicji Kasman-Kreczmar, architekta, siostry działacza KPP, a wtedy PPR. Kreczmarowie mieli już dwójkę dzieci, Tomasza i Agnieszkę, dla których Axer pisał bajki. Jednak, żeby nie sprowadzać zagrożenia dla czteroosobowej rodziny, wkrótce Axerem zaopiekowała się samotna Bronisława Kreczmarówna, siostra stryjeczna Jana i Jerzego, mieszkająca na parterze przy ulicy Henryka Siemiradzkiego. Axer wychodził z nią wieczorami i spacerował przynajmniej po ulicach Krasińskiego czy Pawła Suzina i placu Thomasa Woodrowa Wilsona, nie bez powodu obawiając się rozpoznania. ${ }^{22}$ Ale nade wszystko czytał książki z biblioteki pozostałej po sowietologu i oficerze polskiego wywiadu, Jerzym Niezbrzyckim, czyli Ryszardzie Wradze. Dochodził do równowagi psychicznej po lwowskich doświadczeniach niedoszłej ofiary „ostatecznego rozwiązania” kwestii żydowskiej. W kwietniu i maju 1943 być może widział z żoliborskiego mieszkania słup dymu nad likwidowanym gettem warszawskim, w którym toczyło się powstanie. W 1943 roku napisał obok innych wiersz List do Lwowa.

Czasem w nocy - wyznał Axer w Polowaniach - znowu bywam osaczony przez Niemców. Znowu jestem poza prawem i wiem, że nie ma dla mnie wyjścia. Boję się tysiąc razy bardziej niż wtedy gdy z narzędziami w blaszanej puszce pod pachą przemierzałem miasto. Plandeki na ciężarówkach falują, zakrywając pole widzenia, z balkonu na Zamarstynowie, nad głowami gawiedzi zwisają trupy „Judenratów”. Znowu Ryś jest w obozie, a ja chodzę po Łąckiego, wypatrując w oknach więzienia twarzy ojca. ${ }^{23}$

20 Idem, Polowania, [w:] Ćwiczenia pamięci, op. cit., s. 97.

${ }_{21}$ Zob. M. Zielińska, Punkty widzenia. Rozmowa ze Zbigniewem Zapasiewiczem, „Notatnik Teatralny" 2005 nr 36-37, s. 65.

${ }_{22}$ Zob. E. Axer, Koledzy, [w:] idem, Ćwiczenia pamięci. Seria trzecia, op. cit., s. 135-136.

23 E. Axer, Polowania, op. cit., s. 98 
Ale już w Ćwiczeniu pamięci, wydrukowanym w „Dialogu” we wrześniu 1989, gdy cenzura komunistyczna praktycznie przestała działać, a poprzedzonym niemieckojęzycznymi uwagami Eliasa Canettiego o wypartych wspomnieniach, które niekiedy same powracają, i zawierającym spisane w trzeciej osobie reminiscencje z wędrówki „do pracy” przez Lwów okupowany przez nazistowskie Niemcy, jedynie wzmianka o przejściu „do «aryjskiej» dzielnicy” nie pozostawia wątpliwości, że rzecz dotyczy getta z drugiej połowy 1942 już ograniczonego do dzielnic Zamarstynów i Kleparów. ${ }^{24}$ W opublikowanej natomiast w 1991, przeprowadzonej jednak jeszcze w 1987, rozmowie Elżbiety Wysińskiej z Axerem doświadczona we Lwowie okupowanym przez Niemców „okrutna katastrofa”, w trakcie której był on zdany „,na pomoc nielicznych” ${ }^{25}$ przywołana została wyłącznie poprzez felieton z roku 1960 O snach. Podobnie w biogramach redagowanych przez Axera albo pod jego okiem żydowski rodowód był pomijany bądź zaledwie sygnalizowany osobom znającym wojenne realia. ${ }^{26}$ Axerowi, uformowanemu najpierw przez kulturę niemiecką, a potem polską, w getcie lwowskim została niejako narzucona tożsamość żydowska, której znakiem była noszona przymusowo opaska z gwiazdą Dawida. Mógł z jej powodu zostać zamordowany jak ojciec i brat. Axer żydowskiego rodowodu bynajmniej uporczywie nie ukrywał, jak choćby Stanisław Lem, który, jak dowiedli niedawno znawcy jego pisarstwa, wypierał z pamięci swe doświadczenia z czasu Zagłady we Lwowie, nawiązując do nich jedynie w dziełach literackich. ${ }^{27}$ Ale Axer też starał się - szczególnie w Polsce komunistycznej instrumentalnie traktującej pamięć o Zagładzie nie tylko w latach 1967-1968 28 żydowskiego pochodzenia nie demonstrować.

24 Zob. idem, Ćwiczenie pamięci, [w:] idem, Ćwiczenia pamięci. Seria druga, op. cit, s. 156-158. Motto z Canettiego po polsku w przekładzie Marii Przybyłowskiej brzmi następująco: „Pamięć się kończy. Jednak wszystko jest nadal obecne. Nawet to najbardziej zapomniane znowu się zgłasza. Ale tylko wtedy, kiedy samo chce".

25 Uktadanie biografii, op. cit., s. 656.

26 Zob. E. Axer, Ćwiczenia pamięci, op. cit. W biogramie wydrukowanym na obwolucie znajduje się wzmianka, że w latach 1941-1942 „był ślusarzem”. Elżbieta Baniewicz podaje, że Axer „lakierował samochody”, a potem „dorabiał klucze”, bo Niemcy po zajęciu Lwowa w 1941 „w lipcu ogłosili zarządzenie o przymusowej pracy dla mieszkańców miasta”. Dotyczyło ono jednak wyłącznie Żydów w przedziale wiekowym od 14 do 60 lat. Zob.: E. Baniewicz, Erwin Axer. Kronika życia i twórczości, „Notatnik Teatralny” 2005 nr 36-37, s. 352; eadem, Erwin Axer: teatr słowa i myśli, Kraków 2010, s. 76-79, 444-445. Równocześnie napisana przez Ewę Małkowską-Bieniek wspólna sylwetka dwóch Axerów: Erwina i brata stryjecznego jego ojca, scenografa - Ottona znalazła się w popularnym słowniku biograficznym Żydzi polscy. Historie niezwykte, Warszawa 2010, s. 18-20. Chociaż można się z niej jedynie dowiedzieć, że w czasie Zagłady Erwin Axer po aresztowaniu ojca pod koniec 1942 wyjechał ze Lwowa do Warszawy. Dopiero w Przedmowie do dwujęzycznego wyboru prozy Axera - wydanego już po moim wystąpieniu na sesji w Akademii Teatralnej - Baniewicz zdawkowo opowiedziała o jego doświadczeniach w czasie wojny, nie pomijając „pochodzenia żydowskiego”. Zob. E. Axer, Polsko-niemieckie ćwiczenia pamięci. Polnisch-deutsche Gedächtnisübungen, wybór E. Baniewicz i A. Rabińska, Warszawa 2017, s. 11-12.

27 Zob. A. Gajewska, Zagłada i gwiazdy. Przeszłość w prozie Stanisława Lema, Poznań 2017.

28 Zob. M. C. Steinlauf, Pamięć nieprzyswojona. Polska pamięć Zagłady, przekł. A. Tomaszewska, Warszawa 2001. 
Ze sporą dozą ironii rozpamiętywał za to sytuacje, gdy w międzywojennej Polsce przypominano mu o nim. W listopadzie 1932 jako ,potomek przodków cudzoziemskich" pozbawiony został przez kuratora tytułowej roli w Ślubach Jana Kazimierza, odegranych przez uczniów szkół średnich na scenie Teatru Wielkiego z okazji ćwierćwiecza śmierci Wyspiańskiego. ${ }^{29}$ Również w trakcie studiów w Państwowym Instytucie Sztuki Teatralnej w Warszawie, gdzie w 1938 doszło do konfliktu z powodu zwolnienia dwóch wykładowców żydowskiego pochodzenia, socjologa Aleksandra Hertza i historyka sztuki Mieczysława Wallisa przez dyrektora Stanisława Adamczewskiego, odwołanego potem pod wpływem protestów ze stanowiska przez Ministerstwo Wyznań Religijnych i Oświecenia Publicznego, Axerowi zdarzały się podobne sytuacje. W lutym 1937, gdy niemiecka aktorka Emma Sonnemann, jako żona składającego wizytę w Polsce premiera Prus i marszałka Trzeciej Rzeszy, Hermanna Göringa, oglądała w Narodowym inscenizację Fieska, na polecenie Leona Schillera, który prawdopodobnie pozwolił sobie na ,żart”, Axer musiał jej towarzyszyć w loży, chociaż, jeśli podzielała rasistowskie uprzedzenia nazistów, powinna uważać, że jest „czymś w rodzaju szympansa, goryla, pitekantropusa" ${ }^{30}$ Przypuszczenia Axera nie były bezzasadne. Inny jego nauczyciel z PIST-u, reżyser Edmund Wierciński, w liście z 6 marca 1939, donosząc żonie Marii, iż we Lwowie był „na kolacji u Axerów” podkreślił, że oprócz niego zaproszonych „było kilku Żydów i Żydówek”. Wierciński dostrzegł w rozmowach prowadzonych u Axerów „dużo typowo semickiego snobizmu”, zaś „,W mieszkaniu jakiś specyficzny, rasowy zapaszek”. „A przecież nie jestem antysemitą!" ${ }^{31}$ - deklarował przyszły autor Gałazek akacji ${ }^{32}$, zawierających opis likwidacji getta w Otwocku i będących zapewne pierwszą w polskiej literaturze reakcją na Zagładę.

$\mathrm{W}$ przeciwieństwie do również ocalonego z getta lwowskiego absolwenta PIST-u, Aleksandra Bardiniego, Axer nigdy nie reżyserował ani bodaj nawet nie był w Izraelu. Chociaż namawiał go na przyjazd reżyser Michał Weichert, twórca jidyszowego Teatru Młodych, oglądanego w czasach PIST-u, od 1958 mieszkający w Tel Awiwie. W liście z 5 lutego 1960 pytał:

Czy nie myśli Pan kiedyś o wizycie w Izraelu? Gdyby Pan się zdecydował przyjechać tu jako turysta lub zechciał wystawić jakąś rzecz w teatrze - chętnie służę pomocą.

Ponieważ Axer zignorował pytanie, do sprawy tej powrócił Weichert w liście z 9 marca 1960:

Jak Panu wiadomo jestem człowiekiem upartym. Powtarzam więc moje pytanie oraz gotowość pomocy we wszelkiej formie. Chętnie bym przyłożył rękę do wystawienia sztuki przez Pana w jed-

29 E. Axer, Debiut, [w:] idem, Ćwiczenia pamięci, Seria trzecia, op. cit., s. 110-114.

30 Idem, Żart, [w:] idem, Ćwiczenia pamięci, Seria trzecia, op. cit., s. 115-119.

31 M. i E. Wiercińscy, Korespondencja 1925-1944, oprac. M. Piekut, Warszawa 2013, t. 1, s. 416.

32 Zob. E. Wierciński, Gałąki akacji, [w:] idem, Notatki i teksty z lat 1921-55, wybór i red. A. Chojnacka, Wrocław 1991. 
nym z tutejszych teatrów czołowych. A może by Pan zechciał myśleć o przyjeździe Teatru Współczesnego ${ }^{33}$

W rezultacie Tango Sławomira Mrożka w Habimie w Tel Awiwie 7 marca 1967 wyreżyserował Bardini. ${ }^{34}$ Axer zaś wcześniej przeniósł swą warszawską realizację Tanga na scenę niemiecką.

Na jedyną zasadniczą konfrontację z tematem Zagłady na scenie Axer zdobył się, wystawiając w lipcu 1966 we Współczesnym w Warszawie - w ślad za największymi teatrami niemieckojęzycznymi, przede wszystkim działającą w Berlinie Zachodnim Freie Volksbühne Erwina Piscatora - Dochodzenie Petera Weissa, oparte na dokumentacji frankfurckiego procesu funkcjonariuszy obozu Auschwitz-Birkenau, toczącego się w latach 1963-1965. Axerowi niewątpliwie odpowiadało, że w „oratorium w jedenastu pieśniach" Weissa - niemieckiego dramatopisarza mającego semicki rodowód - mordowani w komorach gazowych ani razu nie są nazwani Żydami.

Grzegorz Niziołek sugerował w niedawno wydanym Polskim teatrze Zagłady, że Dochodzenie to najwybitniejsze przedstawienie wśród dokonań reżyserskich Axera. ${ }^{35}$ Przywołał opublikowane w $1990 \mathrm{w}$ tomie poświęconym czterdziestoleciu Teatru Współczesnego Wspomnienie Zbigniewa Raszewskiego o tym przedstawieniu, które uznał za ,jedno z najbardziej niezwykłych" "36, jakie widział w całym swym życiu. Szkoda zresztą, że Niziołek nie znał - będącego jego istotnym dopełnieniem, a ogłoszonego rok wcześniej w tomie tekstów ofiarowanych Raszewskiemu - szkicu Tadeusza Łomnickiego o granej w Dochodzeniu roli Świadka VI, lekarza, a niegdyś funkcyjnego w obozowym szpitalu i osobistym stosunku aktora do Zagłady. ${ }^{37} \mathrm{~W}$ każdym razie Raszewski - bezpodstawnie oskarżany przez Niziołka o ignorowanie Zagłady i antysemityzmu Polaków - wyraźnie przeciwstawiał ascetyczną i powściągliwą realizację Dochodzenia, przepojoną ,,szacunkiem dla cierpienia, o którym się w sztuce mówi", powszechnie podziwianej inscenizacji Kariery Artura Ui. Podobnie ,wewnętrznie wypalonego" Świadka VI z Dochodzenia wyżej cenił niż tytułową rolę w dramacie Bertolta Brechta, uznawaną zgodnie za najwybitniejszą w dorobku Łomnickiego. Na pewno więc trzeba docenić krótko grane we Współczesnym Dochodzenie, ale też analizować pozostałe przedstawienia Axera przez pryzmat jego bolesnych doświadczeń z czasu Zagłady. Przecież nawet ich stylistyka wynikała z odrzucenia estetyki widowisk i ceremonii politycznych słu-

33 Listy Michała Weicherta do Erwina Axera, Instytut Teatralny w Warszawie. Zob. R. Węgrzyniak, Procesy doktora Weicherta, Warszawa 2017, s. 96, 308-310, 326-327.

34 Zob. M. Dworakowska, Aleksander Bardini. Kronika życia i działalności (1913-1995), „Pamiętnik Teatralny" 2010 z. 3-4, s. 111-112. Wcześniej, w 1964 Bardini wystawił Franka V Dürrenmatta w Hajife (s. 104).

35 Zob. G. Niziołek, Polski teatr Zagłady, Warszawa 2013, s. 57-58, 247-248, 267-273.

36 Zob. Z. Raszewski, Wspomnienie (,,Dochodzenie” Weissa, 1966), [w:] idem, Spacerek w labiryncie. O teatrze polskim po roku 1958, wybór i oprac. J. Timoszewicz, Warszawa 2007, s. 254-259. W tomie jest też natychmiastowa ocena Dochodzenia zanotowana w liście do Jerzego Gota z 29 XII 1966 (s. 229).

37 Zob. T. Łomnicki, Świadek, [w:] O teatrze i dramacie. Studia-przyczynki-materiaty, Wrocław 1989, s. 409-415. 


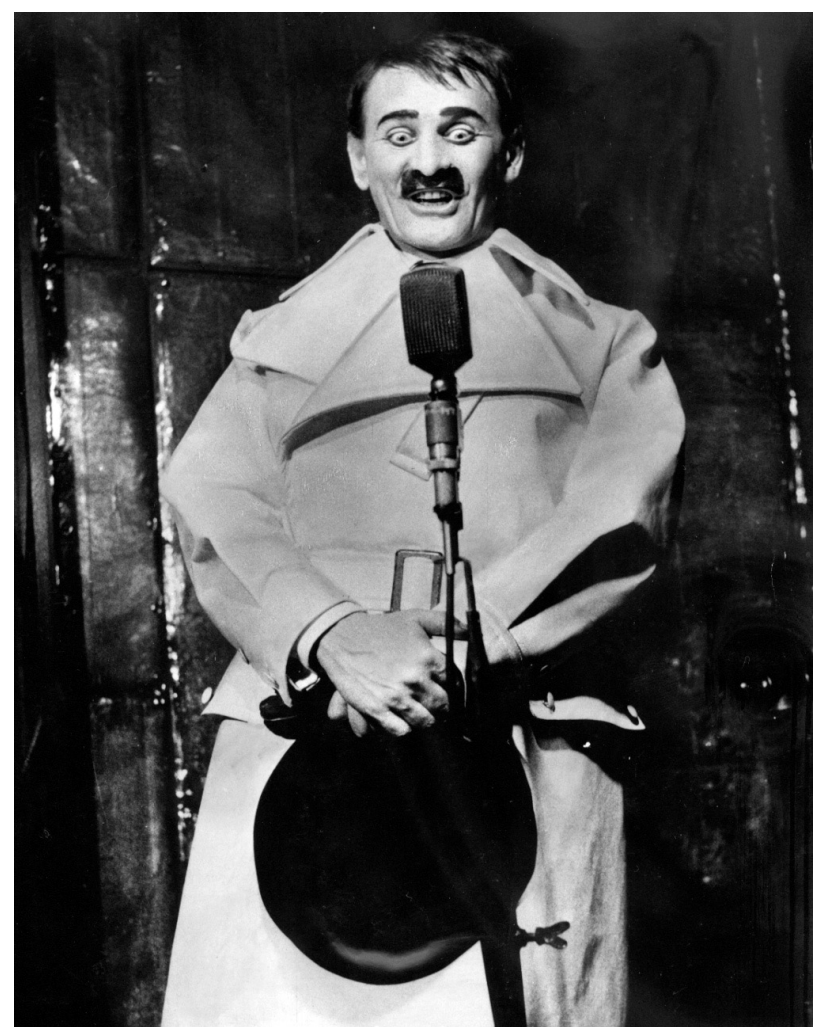

Tadeusz Łomnicki w Karierze Artura Ui Bertolta Brechta, reż. Erwin Axer,

Teatr Współczesny w Warszawie, prem. 6 I 1962. Fot. Edward Hartwig

żących propagowaniu narodowego socjalizmu oraz innych ideologii totalitarnych. A istotną rolę w nich pełniło współistnienie żywych z umarłymi. ${ }^{38}$

We wrześniu 1984 Axer w felietonie opublikowanym w „Dialogu” napomknął, że „w Berlinie” obejrzał „sztukę” czy „raczej musical”, którego tematem jest ,getto wileńskie czasu wojny”, a ściślej działający w nim teatr. Zdradził tylko, że dramat napisał autor „wychowany w Palestynie”, a zainscenizował reżyser dorastający „w Anglii”. Nietrudno ustalić, że Axer we Freie Volksbühne w Berlinie Zachodnim był na premierze Getta Joszuy Sobola w reżyserii Petera Zadka. Podkreślił, że publiczność płakała, ale „kilka osób wyszło, trzaskając drzwiami”. On sam również zbulwersowany potraktowaniem Zagłady jako tematu na musical i reakcjami niemieckich widzów, wśród których mogli się znaleźć esesmani

38 Zob. R. Węgrzyniak, Kompleks Schillera, „Notatnik Teatralny” 2005 nr 36-37; idem, Pomiędzy dwoma teatrami, ,Teatr” $2013 \mathrm{nr} 1$. 
z lwowskiego getta, opuścił niegdysiejszy teatr Piscatora dyskretnie, bo „dopiero w połowie. W czasie przerwy". ${ }^{39}$

W październiku 2001 Axer zrezygnował z udziału w pracach jury przyznającego nagrodę literacką Nike. Uczynił to demonstracyjnie, bo tuż przed rozstrzygnięciem, ale bez publicznych wyjaśnień. Wszystko wskazywało na to, iż w kręgu „Gazety Wyborczej” postanowiono ze względów politycznych uhonorować nią studium historyczne Jana Tomasza Grossa Sąsiedzi usiłujące dowieść, że Polacy - nie tylko mieszkańcy podlaskiego miasteczka Jedwabne - byli współsprawcami Zagłady. Axer najwyraźniej nie chciał brać w tym udziału. ${ }^{40}$ Będąc we Lwowie świadkiem zorganizowanego przez Niemców pomiędzy 25 a 27 lipca 1941 trzydniowego pogromu, w trakcie którego Ukraińcy zamordowali dwa tysiące Żydów, musiał mieć wątpliwości dotyczące wiarygodności przynajmniej niektórych historycznych tez Grossa. Raczej nie podzielał przekonania wyrażanego również przez Grossa, że współodpowiedzialność za Zagładę europejskich Żydów spoczywa na Kościele rzymsko katolickim, skoro pod koniec życia, tuż przed śmiercią w 2012, przyjął chrzest. Wcześniej, w trakcie powstania warszawskiego, został ochrzczony „z wody” na wypadek nagłej śmierci.

Od 1 sierpnia 1944 Axer uczestniczył bowiem w powstaniu warszawskim na Żoliborzu zostawszy, jak wspominał, na początku jedynie członkiem „Wojskowo-Saperskiej Pomocy Technicznej”. „W natarciu na dworzec Gdański” - dwukrotnie prowadzonym między 20 a 22 sierpnia i mającym utorować drogę, która połączyłaby Żoliborz ze Starym Miastem - brał udział jeszcze „, łopatą w ręku zamiast broni”. ${ }^{41}$ Dopiero pod koniec powstania otrzymał „pepeszę i prawdziwą opaskę", więc czuł się ,żołnierzem”. Przy czym w dokumentacji Muzeum Powstania figuruje jako używający konspiracyjnego nazwiska Gomulski, fotoreporter w zgrupowaniu „Żyrafa” II Obwodu „Żywiciel” Warszawskiego Okręgu AK.42

\footnotetext{
39 E. Axer, Pokaż mi swoje sztuczki, powiedziat żolnierz... , [w:] idem, Ćwiczenia pamięci. Seria druga, op. cit., s. 17.

40 Zob. V. Ozminkowski, Lwowianin, Polak, Europejczyk. Pożegnanie Erwina Axera, „Newsweek Polska” 15 VIII 2012. W tym pełnym błędów nekrologu Axera Elżbieta Baniewicz utrzymywała, że „etyka zawodowa nie pozwalała mu podpisać się pod nagrodą literacką dla książki, która literaturą nie była". Natomiast w zrelacjonowanej mi przez Marka Radziwona rozmowie, przeprowadzonej przez niego już po moim wystąpieniu na sesji 20 X 2017, ówczesny sekretarz jury, Michał Cichy, który wcześniej, w 1993 na łamach „Gazety Wyborczej”, utrzymywał, że w trakcie powstania warszawskiego AK wymordowała ukrywających się Żydów, twierdził, iż Axer jedynie źle znosił dominację jego przewodniczącej Marii Janion. Ostatecznie Gross nie został uhonorowany nagrodą.

${ }^{41} \quad$ Uktadanie biografii, op. cit., s. 656.

42 Zob. G. Jasiński, Żoliborz 1944. Dzieje militarne II Obwodu Okręgu Warszawa AK w Powstaniu Warszawskim, Pruszków 2009. W opublikowanym na końcu tej monografii ,wykazie żołnierzy Armii Krajowej walczących w II Obwodzie podczas powstania warszawskiego 1944 r." figuruje jedynie „Bronisława Kreczmar Axel[!]-Gomólska Donia 1915” (s. 421).
} 
Dowodził nim pułkownik Mieczysław Niedzielski, który od 4 sierpnia kontrolował Żoliborz, współistniejąc z silnymi w tej dzielnicy - zamieszkałej przez lewicową inteligencję - oddziałami Armii Ludowej. Żoliborskie oddziały AK skapitulowały 30 września po daremnej próbie przebicia się do Wisły i przeprawienia na jej prawy brzeg łodziami przysłanymi przez armię polską Zygmunta Berlinga. Axer uczestniczył w tej operacji, ale odmówił wsparcia - chyba oddziałowi AL - broniącemu barykady przy ulicy Alojzego Felińskiego, mającej osłaniać „natarcie na Wisłę", utrzymując, że nie umie strzelać. ${ }^{43} \mathrm{~W}$ nocy z 30 września na 1 października Axer i Kreczmarówna, która była łączniczką AK, opuścili Żoliborz, maszerując przez Bielany i Wolę wraz z ludnością cywilną. Wyprowadził ich major Władysław Nowakowski, „Żubr”, który, jak potem wyjaśnił, wolał udać się do „niemieckiej niewoli”, niż przedzierać „na Pragę”, skąd żołnierzy AK Sowieci wysyłali do syberyjskich łagrów. ${ }^{44}$

Axer został więc wraz z Nowakowskim wywieziony jako jeden z 2655 jeńców do pięćdziesięciotysięcznego i międzynarodowego stalagu, czyli obozu dla szeregowców i podoficerów nr XI A w Altengrabow koło Magdeburga w Dolnej Saksonii na terenie Trzeciej Rzeszy. Wbrew konwencji genewskiej znalazł się w komandzie pracującym w kamieniołomach w górach Harzu w pobliżu miasta Elbingerode. Chyba 14 kwietnia 1945 koło Quedlinburga, w trakcie ewakuowania z niemiecką eskortą jeńców pracujących w kamieniołomie lub w kopalni manganu „z gór Harzu ku nizinom na wschodzie”, został uwolniony przez armię Stanów Zjednoczonych. A ściślej poprowadził jeńców bez eskorty Niemców w stronę amerykańskich żołnierzy. Wraz z grupą powstańców pozostał ponad dwa miesiące w miasteczku Halberstadt i starał się nie dopuszczać do bicia i poniżania Niemców. Chociaż wziął udział w publicznym wymierzeniu kary cielesnej na rynku w Elbingerode majstrowi, który bił jeńców zmuszanych do pracy w kamieniołomie. ${ }^{45}$ W Halberstadt odnalazła go Kreczmarówna, również wywieziona z Warszawy po powstaniu. W Magdeburgu Axer został przez Amerykanów przydzielony do Military Government Polish Departament. W lipcu 1945 z Kreczmarówną, swą przyszłą żoną, wrócił do Polski, a ściślej do Łodzi i zamieszkał w tamtejszym Domu Aktora. ${ }^{46}$

Doświadczenia z lat wojny i Zagłady Axer zaczął spisywać już w niemieckim stalagu. Bodaj pierwszym jego tekstem powstałym w obozie jenieckim był Odwrót 1939 odtwarzający przeżycia z przełomu sierpnia i września, w 1946 opublikowany częściowo, do momentu wkroczenia Sowietów, na łamach łódzkiej „Kuźnicy”, a w 2003 przedrukowany z komentarzem w Czwartych ćwiczeniach pamięci. Doświadczenia wojenne znalazły też wkrótce odbicie w przedstawieniach Axera po-

43 Zob. E. Axer, Mój problem Lorda Jima, [w:] idem, Ćwiczenia pamięci, op. cit., s. 199-202.

44 Zob. idem, Exodus, [w:] idem, Ć́wiczenia pamięci. Seria trzecia, op. cit., s. 140-142.

45 Zob. idem, Na moście, Wyzwolenie, Pierwszy, drugi i trzeci dzień wolności, Majówka, [w:] idem, Ćwiczenia pamięci. Seria druga, op. cit., s. 19-22, 115-142, 166-169.

46 Zob. idem, Powrót 1945, [w:] idem, Czwarte ćwiczenia pamięci, op. cit., s. 199-206. 
wstałych w Łodzi w Teatrze Kameralnym Domu Żołnierza. Najpierw w rozgrywającej się w okolicach okupowanej Warszawy, w Pruszkowie i w Podkowie Leśnej, Starej cegielni Jarosława Iwaszkiewicza z kwietnia 1946. W tej noweli, napisanej w 1943 i adaptowanej przez autora na scenę, istotną rolę pełni ukrywanie Karola, który, uciekając z pociągu, został postrzelony przez Niemców i potrzebuje fałszywej kennkarty, zostaje zaś zadenuncjowany. Axerowi zamierzał Iwaszkiewicz także powierzyć przygotowanie prapremiery sztuki Pod Akacjami toczącej się w podobnych realiach wojennych, gdyż w Podkowie na początku 1944. Jej protagonistą jest harcerz Józio, mający z rozkazu podziemnej organizacji zastrzelić zdrajcę. Poza nim $\mathrm{w}$ dramacie występują przejęty moralnymi rozterkami wykonawcy wyroku „ksiądz [Węgrzyn] w sile wieku”, ,,aptekarz-filozof”, „konduktor EKD” i „,młody, przystojny Niemiec". ${ }^{47}$ Jednak utwór nie doczekał się wystawienia zaraz po wojnie, a został opublikowany dopiero po śmierci Iwaszkiewicza, w roku 1983.

W październiku 1946 Axer natomiast odmówił wyreżyserowania w Teatrze Powszechnym TUR w Łodzi dyskredytującego Armię Krajową z pozycji komunistycznych Starego dworku Adama Ważyka, awangardowego poety żydowskiego pochodzenia, przebywającego w czasie wojny w Związku Sowieckim, w tym do połowy 1941 we Lwowie. Axer odrzucił propozycję pomimo nacisków ze strony Schillera, który niedawno wrócił z niemieckiego obozu do Polski.

W sztuce - thumaczył Axer swą decyzję w roku 1991 - oddział AL zaplątany jest w bitwę, a AK zgodnie z oficjalną (wówczas) tezą o „staniu z bronią u nogi”, nie chce pomóc. Zaciąłem zęby i odmówiłem..$^{48}$

Lecz zakłamany obraz początku wojny we wrześniu 1939 oraz okupacji sowieckiej wschodnich ziem Polski zaprezentował Axer pod koniec kwietnia 1953, w dwa miesiące po śmierci Josifa Stalina, w realizacji scenicznej, a potem filmowej, Domku z kart Emila Zegadłowicza w opracowaniu Ważyka. Szczególnie w epilogu z dwoma krasnoarmiejcami ukazanymi jako wyzwoliciele, bo zdejmującymi kajdany z rąk transportowanego do obozu w Berezie Kartuskiej lewicowego inteligenta, Brunona Sztorca. ${ }^{49}$

W styczniu 1965, z kolei w ramach obchodów dwudziestolecia Polski komunistycznej, Axer wystawił we Współczesnym, utrzymaną w konwencji teatru epickiego Brechta, sztukę Jerzego Broszkiewicza Przychodzę opowiedzieć. Jej protagonistą był Jan Polok, grany przez Zbigniewa Zapasiewicza, inteligent urodzony w roku 1919. Krytyce w niej poddane zaś zostało zarówno reprezentowane

47 „Chcialbym się z Toba naprawdę zaprzyjaźnič”: korespondencja Erwina Axera i Jarostawa Iwaszkiewicza, spisał i oprac. P. Rudzki, „Notatnik Teatralny” 2005 nr 36-37, s. 178-182, 187. Edytor utrzymywał, że „nie wiadomo, o którym dramacie pisze Iwaszkiewicz”, chociaż Pod Akacjami wydrukował „Dialog” $1983 \mathrm{nr} 4$.

48 Lódź, Teatr Kameralny. Z Erwinem Axerem rozmawia Elżbieta Wysińska, „Teatr” 1994 nr 6, s. 10. Spektakl wyreżyserował ostatecznie Władysław Krasnowiecki, niegdysiejszy kierownik artystyczny PPTD we Lwowie.

49 Zob. J. Lipiński, Na marginesie prapremiery „,Domku z kart”, „Pamiętnik Teatralny” 1954 z. 2. 
przez Sierżanta sanacyjne wojsko polskie, we wrześniu 1939 ponoszące klęskę, jak i Armia Krajowa, w której Major Szary, odtwarzany przez Jana Kreczmara, organizował nieudany zamach na niemieckiego dygnitarza z udziałem grupy młodych żołnierzy.

Ambiwalentną ocenę powstania warszawskiego jako walki podjętej z bronią słabą i nierówną wobec tej, jaką dysponował wróg, oraz przejawu lekkomyślności czy nawet szaleństwa, wygłaszał w trakcie przemarszu grupy dzieci w hełmach z polskimi znakami, Dyrektor w Dwóch teatrach Szaniawskiego, wystawionych przez Axera we Współczesnym w lipcu 1968, a także w grudniu 1969 w Wielkim Teatrze Dramatycznym w Leningradzie. Wreszcie w lutym 1975 Axer wyreżyserował we Współczesnym dramat poetycki Ernesta Brylla Rzecz listopadowa. W spektaklu powojenną Warszawę, egzystującą poniekąd na cmentarzu, w Zaduszki osądzali polegli w sierpniu lub wrześniu 1944 powstańcy, którzy jakby wyszli z kanałów w rozkładających się mundurach AK: Pierwszy i Drugi.

Jeszcze w Łodzi w Szklanej menażerii Tennessee Williamsa, wystawionej w marcu 1947, nawiązał Axer do niedawno zakończonej wojny w dopisanym przez siebie epilogu, oddając hołd amerykańskim żołnierzom, którzy wyzwolili Europę Zachodnią i tym samym jego „odbili z niewoli w Niemczech”. Uważał, że „bez nich wciąż jeszcze Europą rządziłby Hitler”. ${ }^{50}$ Do wojennych doświadczeń Axer odwołał się też pośrednio, reżyserując - ukazującą męczeństwo działaczki zapewne nie tylko francuskiego ruchu oporu - Joanne z Lotaryngii Maxwella Andersona w czerwcu 1948. Scena w sądzie w podtekście była przesłuchaniem przez Gestapo bez tortur. Dlatego Axer zabronił płakać grającej zarazem Joannę d'Arc i odtwarzającą ją amerykańską aktorkę Irenie Eichlerównie, która pragnęła odpokutować w ten sposób swą nieobecność w okupowanej Polsce.

4.

Axer zademonstrował swój stosunek do urzeczywistniania przez Niemców ideologii narodowego socjalizmu, wystawiając w Warszawie dwukrotnie dramat Leona Kruczkowskiego toczący się w 1943 w okupowanej Europie, w Norwegii, Francji i w Generalnym Gubernatorstwie, gdzie zabijane jest żydowskie dziecko, oraz w Getyndze, w domu profesora tamtejszego uniwersytetu - Sonnenbrucha. Sztukę Kruczkowski początkowo zatytułował Niemcy też ludzie. Pokazywał bowiem Niemców - zaraz po wojnie pisanych dla zademonstrowania pogardy z małej litery i prezentowanych wyłącznie w rolach zbrodniarzy - jako ludzi i starał się zrozumieć ich postępowanie. W spektaklach Axera Hoppe mordujący żydowskiego chłopca był w Getyndze dobrodusznym i troskliwym ojcem rodziny. We Współczesnym w listopadzie 1949 Axer potraktował Niemców jako retrospekcję ujętą w ramy politycznego komentarza dopisanego z pozycji komunistycznych.

50 Łódź, Teatr Kameralny, op. cit., s. 9-10. 


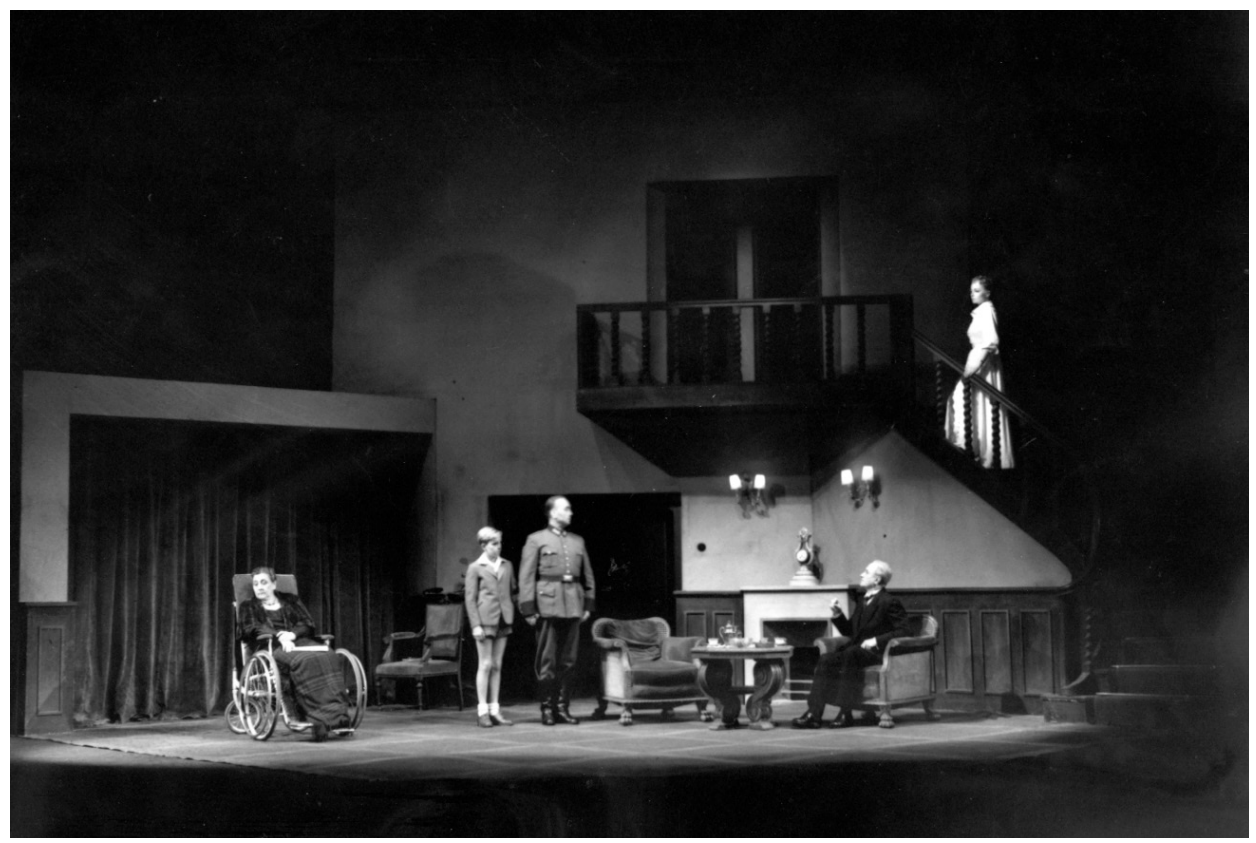

Niemcy Leona Kruczkowskiego, reż. Erwin Axer, Teatr Narodowy w Warszawie, prem. 18 II 1955.

Fot. Franciszek Myszkowski

W Narodowym w lutym 1955 przygotował spektakl utrzymany w stylistyce teatru epickiego Brechta poprzez wprowadzenie napisów lokalizujących akcję i odejście do realistycznych dekoracji. Zrezygnował też w nim z epilogu.

Później Axer Pierwszy dzień wolności Kruczkowskiego, szczególnie bliski jego doświadczeniom po wyjściu ze stalagu, wyreżyserował we Współczesnym w Warszawie w grudniu 1959 oraz w Krakowie w Teatrze im. Słowackiego w lutym 1960. Dramat ukazuje grupę polskich oficerów opuszczających po klęsce Trzeciej Rzeszy obóz jeniecki, w którym spędzili ponad pięć lat, i w opustoszałym miasteczku zatrzymujących się w domu niemieckiego lekarza, będącego ojcem dwóch córek. W spektaklu warszawskim na plan pierwszy wysunęła się zastrzelona na końcu przez Jana, grana przez Aleksandrę Śląską, Inga, która od apatii spowodowanej zgwałceniem przechodziła do fanatyzmu w duchu nazistowskim, woli walki i gotowości zabijania polskich oficerów. Wprawiała się w trans przy dźwiękach niemieckiego marszu odtwarzanego z płyty gramofonowej. A rytmicznymi uderzeniami pięści imitowała odgłosy maszerujących oddziałów Wehrmachtu czy SS.

Axera rozrachunek $\mathrm{z}$ narodowym socjalizmem i zbrodniami dokonanymi $\mathrm{w}$ imię tej ideologii prowadzony był w polskim teatrze niekiedy $\mathrm{z}$ wewnętrznej perspektywy niemieckiej kultury, z którą bynajmniej nie przestał się identyfiko- 


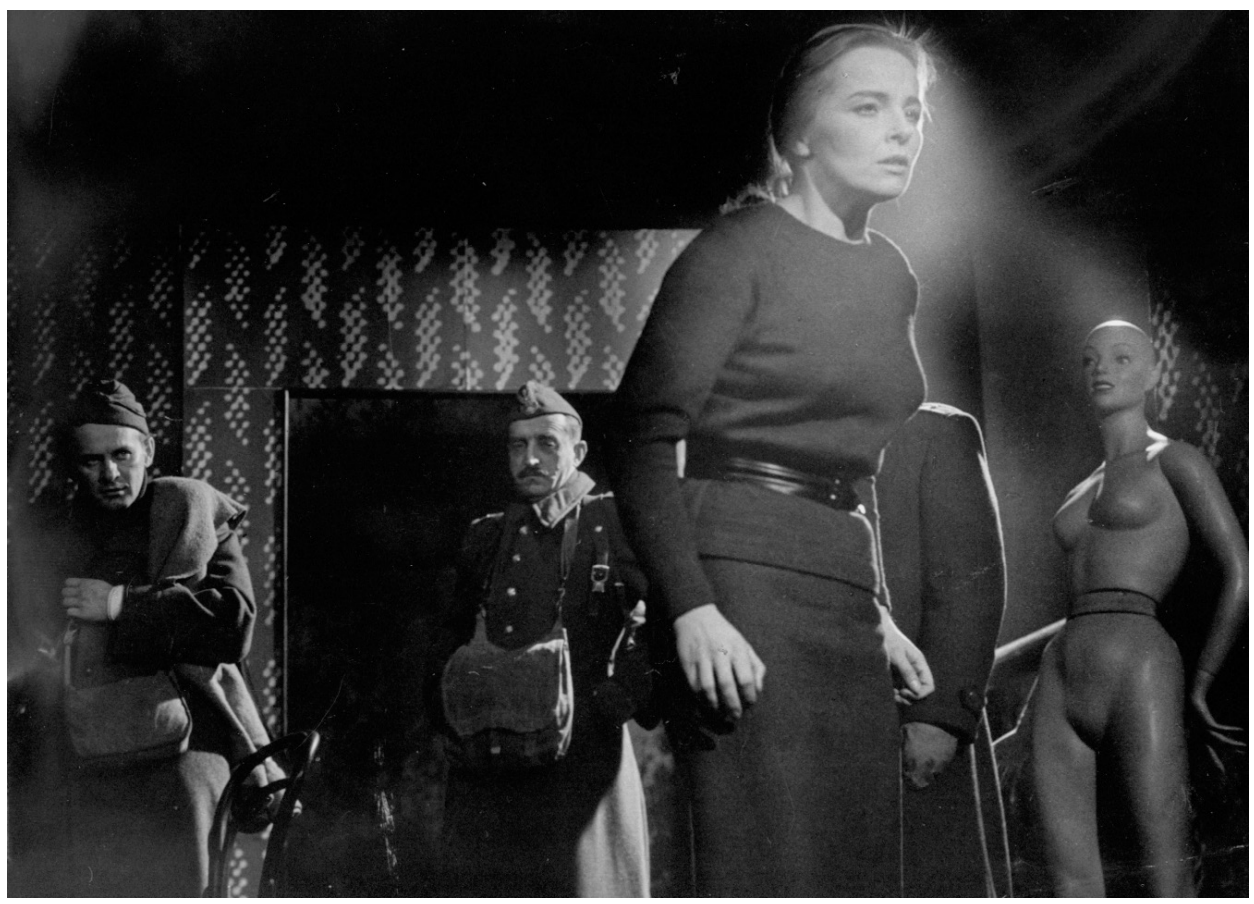

Aleksandra Śląska, Tadeusz Łomnicki i Kazimierz Rudzki w Pierwszym dniu wolności Leona Kruczkowskiego, reż. Erwin Axer, Teatr Współczesny w Warszawie, prem. 17 XII 1959.

Fot. Edward Hartwig

wać. Pierwszą taką próbą było wystawienie we Współczesnym w kwietniu 1959, a następnie w Teatrze Telewizji w październiku 1964, już bez epilogu dziejącego się w Piekle, Biedermanna i podpalaczy Maxa Frischa. W sztuce Frischa panoszenie się w domu Biedermanna dwóch podpalaczy, zapaśnika Schmitza i kelnera Eisenringa, oraz wywołanie przez nich pożaru, było parabolą podporządkowania sobie niemieckiego mieszczaństwa przez nazistów wywodzących się z motłochu. W pewnym momencie grany przez Andrzeja Łapickiego Eisenring, który w epilogu okazywał się Belzebubem, gwizdał ulubioną piosenkę żołnierzy Trzeciej Rzeszy: Lili Marleen. Potem zdobywanie władzy w Niemczech w latach 1933-1938 przez Hitlera i NSDAP, w szerszej skali i bardziej wprost, chociaż nadal poprzez dzieje amerykańskich gangsterów, zademonstrował i skomentował Axer w Karierze Artura Ui Brechta. Zainscenizował ją w stylu ekspresjonistyczno-cyrkowym w styczniu 1962 na scenie Współczesnego w zniszczonej po dwóch powstaniach Warszawie, a w czerwcu 1963 w Wielkim Akademickim Teatrze w Leningradzie, gdzie umarło w trakcie oblężenia milion osób.

Axer nieco obsesyjnie powracał do osoby Hitlera. Jakoby jeszcze w trakcie ukrywania się w Warszawie napisał ,jednoaktówkę Przygoda z Hitlerem”, w któ- 
rej niemiecki dyktator ,występuje po śmierci”. W 1947 rozważał nawet wydrukowanie Przygody z Hitlerem na łamach redagowanych przez Iwaszkiewicza „Nowin Literackich”, gdyż Ważyk po lekturze orzekł, że można ją „opublikować”. Ale w końcu uznał, że komuniści ,zamknęliby chyba pismo razem z Naczelnym $\mathrm{Ob}\left[\mathrm{yw}\right.$ atelem] Redaktorem" ${ }^{11}$ i autorem. Adolfa Hitlera traktował Axer przewrotnie, jak członka rodziny zasługującego na współczucie i niespełnionego twórcę. W 1985 opublikował Krótkie opowiadanie o Adolfie H., w którym w scenerii Monachium przyznał rację Jerzemu Grotowskiemu, że był to w gruncie rzeczy „biedny człowiek”, a „spotkał go los wszystkich pionierów”s2 niezrozumianych i niedocenionych za życia. Axer postępował nieco podobnie jak jego ulubiony pisarz Thomas Mann w opublikowanym w 1939 roku eseju Nasz brat Hitler.

Tak uczynił w Karierze Artura Ui, gdzie tytułowa postać była żałosnym tragikiem pobierającym lekcje deklamacji u Aktora i zalewającym się łzami w trakcie wygłaszania pogrzebowego monologu Antoniusza z Juliusza Cezara Shakespeare'a. Łomnickiego Axer przekonał, aby w jego roli dominowały ,apatia, niewiara, histeryczne uniesienia, szloch, błagania, płaszczenie się przed silniejszymi, rozpacz z powodu niezaspokojenia ambicji". ${ }^{53}$ Z kolei w lutym 1992 wystawił Axer w Thalia Theater w Hamburgu Mein Kampf Georga Taboriego. W sztuce Taboriego, odtwarzany przez Svena-Erika Bechtholfa, Hitler jako niedoszły malarz, nieprzyjęty na studia w akademii, wegetował w Wiedniu w $1910 \mathrm{w}$ noclegowni dla bezdomnych mężczyzn, a do kariery politycznej formowany był przez żydowskiego księgarza Szlomę Herzla.

Znamienne było też, że w rozgrywającym się w kręgu nowoczesnej rodziny Tangu Mrożka - wystawionym najpierw we Współczesnym w Warszawie w lipcu 1965, a następnie w Schauspielhaus w Düsseldorfie w styczniu 1966 - Axer wydobył powinowactwa z Hitlerem domorosłego dyktatora Artura, owładniętego ideą oparcia autorytetu totalitarnej władzy na zadawaniu innym osobom śmierci. Nakazał odtwórcom Artura w trakcie przedśmiertnego monologu, wygłaszanego ze stołu niczym z trybuny, naśladować zachowania Hitlera podczas przemówień. W warszawskim Tangu Wiesław Michnikowski przedrzeźniał więc Łomnickiego grającego Artura Ui. ${ }^{54}$

Axer z racji skomplikowanej tożsamości żydowsko-niemiecko-polskiej oraz uzyskiwania pomocy ze strony potencjalnych wrogów nie był w stanie identyfikować się wyłącznie z ofiarami dwudziestowiecznego ludobójstwa, starał się także zrozumieć sprawców mordów i bodaj nie uległ pokusie uznania ich za

51 „Chciatbym się z Toba....”, op. cit., s. 192-193. Baniewicz w monografii Erwin Axer: teatr słowa i myśli napomknęła jedynie, że to dramat „ściślej o obozach koncentracyjnych”, op. cit., s. 79.

52 E. Axer, Krótkie opowiadanie o Adolfie H., [w:] idem, Ćwiczenia pamięci. Seria druga, op. cit., s.63-64.

53 T. Łomnicki, Praca nad rola Artura Ui, [w:] idem, Spotkania teatralne, wybór i oprac. M. Bojarska, Warszawa 1984, s. 153.

54 Zob. E. Baniewicz, op. cit., s. 248. 
„pozbawionych człowieczeństwa”. Współczesny historyk amerykański, Timothy Snyder, w zatytułowanym właśnie Człowieczeństwo zakończeniu Skrwawionych ziem - poświęconych znanemu Axerowi z autopsji wymordowaniu na rozkaz Stalina i Hitlera pomiędzy rokiem 1933 a 1945 czternastu milionów ludzi w Europie Środkowo-Wschodniej - stwierdził, że od identyfikacji z ofiarami ideologii totalitarnych „ważniejsze moralnie jest zrozumienie działań sprawców. Zagrożenie moralne - zauważył Snyder - nie polega wszak na tym, że moglibyśmy stać się ofiarą, lecz na tym, że moglibyśmy być sprawcą". ${ }^{55}$

55 T. Snyder, Skrwawione ziemie. Europa między Hitlerem a Stalinem, przekł. B. Pietrzyk, Warszawa 2011, s. 431. 